\title{
Det internationale Grundtvig-Seminar 13.-19. august 1972 »A Century after Grundtvig «
}

Den 2. september 1972 var det 100 år siden Grundtvig døde. I den anledning planlagde to selskaber uafhængigt af hinanden afholdelsen af et internationalt Grundtvig-seminar i august 1972: Det danske Selskab og Grundtvig-Selskabet. Allerede 18. september 1970 forelagde Det danske Selskab Grundtvig-Selskabet sin plan. Efter fælles forhandlinger besluttede de to selskaber i begyndelsen af 1972 at forene anstrengelserne sådan, at de af Grundtvig-Selskabet planlagte foredrag, også i forbindelse med det ordinære årsmøde, indgik som led i seminaret »A Century after Grundtvig «, hvortil Det danske Selskab havde udsendt indbydelse gennem side på den anden side regne med deltagelse i seminaret og foredrag gennem at drage nytte af disse kontakter og af de erfaringer, Det danske Selskab har med arrangementet af internationale møder, herunder udflugter til danske højskoler. Det danske Selskab kunde på den anden side regne med deltagelse i seminaret og foredrag af de af Grundtvig-Selskabet indbudte Grundtvig-forskere. Seminaret fik derigennem de bedste muligheder for stort deltagerantal på højt niveau.

Seminaret blev gennemført efter planen på Den internationale Folkehøjskole i Helsingør 13.-19. august 1972 med ialt 64 deltagere fra Canada, Danmark, England, Frankrig, Ghana, Italien, Japan, Mexico, Norge, Rumænien, Schweiz, Sverige, Tyskland og U.S.A. Den forberedende administration og daglige ledelse af seminaret overgik efter fælles overenskomst til direktør Folmer Wisti, Det danske Selskab.

Økonomisk støtte til seminaret er af Det danske Selskab modtaget fra Fællesforeningen for Danmarks Brugsforeninger, Sparekassen København-Sjælland og Tuborgfondet. Denne støtte har 
tillige omfattet udgivelsen af Kaj Thanings bog om Grundtvig på engelsk. Grundtvig-Selskabet har modtaget økonomisk støtte til seminaret fra Undervisningsministeriet, Kirkeministeriet og Carlsen-Langes Legatstiftelse. Denne støtte omfatter også udgivelsen af foredrag fra seminaret i nærværende bind af Grundtvig-Studier. En del af oplaget udsendes af Det danske Selskab til seminarets deltagere og selskabets kontakter iøvrigt.

Da seminarets sprog var engelsk, er indholdet af dette bind altså for en stor dels vedkommende affattet på engelsk, dog med en forkortet gengivelse på dansk. De dansksprogede bidrag til Grundtvig-Studier er som sædvanlig suppleret med en kort sammenfatning på engelsk.

William Michelsen 